Saudi Journal of Business and Management Studies Abbreviated Key Title: Saudi J Bus Manag Stud ISSN 2415-6663 (Print) |ISSN 2415-6671 (Online) Scholars Middle East Publishers, Dubai, United Arab Emirates Journal homepage: https://saudijournals.com

\title{
Analysis Relates to the Influence of Investment Policy, Organizational Strategy and Company Performance towards Corporate Social Responsibility (Study: Manufacturing Sector that Registered and Active on the IDX during 2014-2016)
}

\author{
Aulia Faza ${ }^{1 *}$, Wiwik Utami ${ }^{2}$ \\ ${ }^{1,2}$ Universitas Mercu Buana, Jakarta, Indonesia
}

DOI: $10.36348 /$ sjbms.2021.v06i04.002

| Received: 06.03.2021 | Accepted: 28.03.2021 | Published: 06.04.2021

*Corresponding author: Aulia Faza

\section{Abstract}

This research purpose to further investigate the role of Investment Policy, Organizational Strategy and Company Performance towards Corporate Social Responsibility. This research took 21 companies on manufacturing sector that still active on the IDX during 2014-2016 as research studied. This research were validate the hypothesis which stated that Investment Policy, Organizational Strategy and Company Performance had a partially or wholly affects the Corporate Social Responsibility. Through multiple regression analysis, it was found that the Investment Policy and Company Performance statistically had a positive impact substantially on Corporate Social Responsibility, but not to Organizational Strategy which did not have a substantial impact on Corporate Social Responsibility. Thus, Investment Policy and Company Performance served as the main determinants of corporate social responsibility disclosure in the manufacturing sector in Indonesia.

Keywords: Investment policy, organizational strategy, company performance, corporate social responsibility.

Copyright () 2021 The Author(s): This is an open-access article distributed under the terms of the Creative Commons Attribution 4.0 International License (CC BY-NC 4.0) which permits unrestricted use, distribution, and reproduction in any medium for non-commercial use provided the original author and source are credited.

\section{INTRODUCTION}

Corporate Social Responsibility (CSR) is a corporate social activity which aims to provide benefits to the community and the environment surrounding the company where the company is located, which feels the negative impact of the company's activities. This social activity is mandatory and must be included in the company's financial reports and annual reports as stipulated in Law Number 40 of 2007 which concerns Limited Liability Companies, article 74. More stringent regulations were issued by the Financial Services Authority in the form of OJK Regulation Number 51/POJK.03 / 2017 relating to the Implementation of Sustainable Finance states that public companies in delivering sustainable finance action plans, reporting and publication are required to make a separate sustainability report from the annual report. The implementation of the concept of Good Corporate Governance (GCG) which also as the main subject of
CSR related to organizational governance in all business entities owned by the State is also reflected in Law No.19 of 2003 related to BUMN. The implementation of corporate social responsibility in the environmental aspect like stated in Law Number 32 of 2009 which concerns Environmental Protection and Management, requires companies to manage its environmental impacts resulting from their business activities. Those above points show that the Government as the policy maker has clearly regulated the company's obligations towards social responsibility, including the obligation to submit a sustainable financial action plan, report and publish it to stakeholders.

According to Liputan6.com [1] 20 percent of the companies in Malang Regency were deemed not to meet quality standards for their liquid waste treatment, this has led to BLH as a long-handed member of the Ministry of Environment and Forestry (KLHK) to 
Aulia Faza \& Wiwik Utami., Saudi J Bus Manag Stud, Apr, 2021; 6(4): 114-124

impose sanctions on companies to repair Wastewater Treatment Plants (IPAL). As many as seven companies in the mining and plantation sectors in Bengkulu Province, were given administrative sanctions and paid the penalties to the country for having been proven to pollute the environment. These sanctions and fines were applied by the government to companies that pollute the environment as evidence of the government's seriousness in fighting environmental destroyers [2]. According to Sindonews [3] Wahana Lingkungan Hidup (Walhi) West Java noted that around 30 factories located in the Dayeuhkolot area, Bandung Regency, dispose of waste carelessly into the Citepus river.

The appliance and disclosure of corporate social responsibility in the company is inseparable from the company's commitment in determining the company's investment policy that need to be implemented. Companies which have many interests with their stakeholders would have long-term investment policies that are socially and environmentally sound by implementing better social responsibility which can improve the company's image. Commitment to this investment policy can be view from the capital spend policy made. Companies would benefit financially and non-financially in the future if they carry out their corporate social responsibility in a structured, comprehensive and in sustainable manner, according to this, it would be better if social responsibility becomes an integrated part of the organization's investment policies and business strategies [4].

Apart from the investment policies, companies with good organizational strategies could impact how corporate social responsibility will be implemented and expressed. According to the public, the good image of a product or company would have the convenience of promoting and selling the product or service, so the costs required to promote and sell the product will be more efficient because the product or service has been recognized by the public. Companies which have a poor commitment to investment policies and organizational strategies will view social responsibility as a cost burden for the company and tend to avoid the implementation and disclosure of their social responsibilities, so the investment policies and organizational strategies which are carried out by the company have the potential to cause social and environmental conflicts in the future.

Seeing those phenomenon of social conflict in the form of demands from the community around the company's operations related to investment policies and organizational strategies which considered indifferent to social and environmental problems, it is exacerbated by the company's inability to convey its social responsibility activities to the community and demands from stakeholders for companies. To carry out social and environmental responsibility in investment policies and organizational strategies, there is an opinion that the amount of corporate social responsibility depends on the amount of financial performance and there are differences in results from previous research, so we intend to conduct the research which has limited by the dependent variable, namely Social Responsibility. Companies with Investment Policy, Organizational Strategy and Company Performance as independent variables supported by parameters of firm Size, Leverage/Debt and Research and Development as control variables in manufacturing sector companies which are still active on the IDX during 2014-2016.

\section{THEORETICAL REVIEW}

Stakeholders could be individuals or groups whose with their capacity could affect or be influenced by the impact of organizational activities [5]. The company as an organization cannot stand alone in achieving its personal interests, but also consists of stakeholders such as shareholders, creditors, customers, distributors, government, society, NGOs and others who relates to the organization [6]. The Organizations when carrying out their activities need supports from the strong and solid stakeholders in order to withstand various kinds of pressures, especially the pressure from competitors. Therefore, an organization could be said as strong if it has power internally, legitimacy from external parties and well-measured interests [7].

The company as an entity consisting of stakeholders that must have social responsibility both to shareholders and also to other stakeholders including the community and the environment which are directly or indirectly affected by the organizational activities. Companies which have a concern for their social responsibility will be more mature in planning and executing their business strategies by considering the impact that will be caused by their activities. Therefore, the neutrality, transparency and revealing the CSR disclosure would be the right option in fulfilling stakeholder expectations.

Basically, the legitimacy theory is a theoretical perceived with thoughts based on political economic theory which assumes that society as an external party with its mass power which affects and even determines the leads of the use of resources owned by the organization. Therefore, the legitimacy from society is considered important by organizations in achieving their goals so the organizations would tend to carry out activities and disclosure to social responsibility with an environmental perspective and earn legitimacy from the community [8, 9]. Actually, the social responsibility which is carried out by the company is to synergize its existence to the environment including the community through better CSR disclosure, hoping that the community will justify/support the company's activities for profits $[10,9]$. 
Companies in communicating their social responsibility obligations should be based on its standard that has been prepared by an independent international standard organization, one of that is the Global Reporting Initiative (GRI). In its guidance, GRI divides the social responsibility disclosure indicators specifically into 3 main indicators in the form of economic indicators, environmental indicators and social indicators. Communicating corporate social responsibility also cannot be arbitrary because it involves the interests of stakeholders which is need a special report that is separate from the annual report, namely in the form of a sustainability report which in line with the Association of Chartered Certified Accountants (ACCA) relates to the disclosure of corporate social responsibility.

There has been research conducted to discover the correlation between social responsibility and financial performance, but those research relate to social responsibility and investment policies still have not been explored properly. Therefore, through the use of variety perceptions such as corporate perspective theory [11], stakeholder theory [5, 8, 12], RBV [13, 14, 15], and resource dependency theory (RDT) [16] to fill this gap [17]. McWilliams \& Siegel [11] stated that corporate CSR participation is a response to various stakeholders, including requests from consumers, employees, investors and society. Consumer demand for organic products may require a process of innovation by farmers, as well as product innovation by natural food retailers. Employee demands for progressive policies on workplace relations, safety and workplace facilities may require additional staff members who are trained to implement the CSR policies. Investors such as mutual funds and pension funds increasingly demand their socially responsible investments, which leads to companies trying to realize their products by CSR attributes.

Bertrand \& Schoar [18] analyzed relates to the influence of ability and managerial style to describe how these characteristics affect investment policies and firm performance. According to the same objective and still focused on the effect of CSR participation, the proxy that used was CAPEX (Capital Expenditure) to assess the company's investment policy variables. According to Erhemjamts et al. [17]. Companies that carry out greater social responsibility would have more investment plans in capital expenditures (CAPEX) in order to achieve their long-term goals. Hence the first hypothesis is:

H1: Firm Investment Policy has a positive impact on Corporate Social Responsibility.

In order to decoding and implementing the company policies to achieve company goals it would require a series of specific strategic plans ranging from binding commitments, planning, mplementation and monitoring of integrated company activities Lynch [19] in Wibisono [20]. Organizational strategy is an outline or pattern that becomes a guideline which determines how the organization will develop over time in an efforts to achieve the goals that has been set up and measurable [21]. The company's strategy which is planned to have been implemented or not will be reflected in the daily operations of the company in the form of incurring operational costs. According to this explanation, the proxies that could be used to assess organizational strategy variables are Selling, General and Administrative (SG\&A) Expenses.

Companies with a low level of social responsibility disclosure would have an impact on the high costs that companies have to pay for advertising and Selling, General and Administrative (SG\&A) Expense and conversely [17]. This could be occur because the disclosure of higher social responsibility would able to improve the product image and the company's image in society which makes the product well known to the public so the company would able to cut off the operational costs, especially advertising and selling costs, General and Administrative (SG\&A) Expenses. Corporate social responsibility programs which are structured to the corporate strategy would have a maximum impact on stakeholders including the company itself when it compared to social responsibility programs which only about charity, giving or ceremonial in nature [22]. The company as much as possible will never remove its social responsibility program from its organizational strategy, but it can change as organizational strategy changes. So these are the second hypothesis is:

H2: Organizational Strategy has a positive impact on Corporate Social Responsibility.

Erhemjamts et al. [17] said the ideal level of CSR could be discovered by its cost and benefit analysis. Maximizing company profits will offer a level of CSR which also increases in revenue along with higher costs. As a result, the company would meet the demands from stakeholders and shareholders who demand CSR. The appeal of the firm's perspective theory which successfully integrates to stakeholder theory and resource-based views within a simple demand and supply framework.

According to Orlitzky et al. [23], a survey of literature revealed that there are 3 (three) basic forms that could be used to measure financial performance from an organization, namely: market, accounting and survey measurement, each of which describes the level of stakeholder satisfaction. An efficiency of the company and a subjective point of view of the financial performance itself. Boaventura et al. [18]. Say it is very important to show that there seems to be a correlation between CSP and stakeholder theory. There is a correlation between financial performance and firm 
Aulia Faza \& Wiwik Utami., Saudi J Bus Manag Stud, Apr, 2021; 6(4): 114-124

theory, reminding the efforts to maximize the financial performance which is related to company goals.

In a meta-study on the correlation between CSR and firm performance, Margolis and Walsh [24] reviewed the 109 studies in which CSR has been treated as an independent variable which could predict the firm performance. They concluded that from these 109 studies, 54 showed a positive association, 20 showed mixed results, 28 studies reported an insignificant association, and 7 studies reported a negative association. In previous research, the correlation between CSR and company performance experienced a nonspecific model because variables were omitted, such as R\&D intensity [11] or intangible assets [25]. After controlling for the intent of social strategic decisions, a positive relationship was found between CSR and the company's financial performance or even an inverse correlations [26, 27]. These results illustrated that there are certain company characteristics which encourage managers to adopt social responsibility practices that encourage a statistical correlation between CSR and company performance. Therefore, the third hypothesis was made as:

H3: Firm Financial Performance has a positive impact on Corporate Social Responsibility.

\section{RESEARCH METHODS}

The SPSS program used by researchers to analyzed the multiple linear regression models. This research was included in quantitative research through cross section and time series data as data sources. This research used secondary data from the Indonesian Capital Market Directory (ICMD), financial reports, annual reports and sustainability reports from the websites of each company. The population in this research was the manufacturing sector with all of its sub-sectors that listed and still active on the Indonesia Stock Exchange (BEI) during 2014-2016. The time period of 3 (three) years was chosen so the researcher has enough data variations in order to explain the influence of each variable on the disclosure of corporate social responsibility. The Purposive sampling used to filter the population into samples to be studied so the sample can describe the real conditions of the population. Companies that did not have all the data required for research would be excluded. The total population was 159 companies with the sample obtained after doing purposive sampling filtered was 21 companies.

Related Corporate Social Responsibility Disclosure Index (Related CSRDI) as the dependent variable which used as a proxy for CSR disclosure. The purpose of this proxy modification that to obtained more valid CSRDI because the company's CSR disclosure has been adjusted to the CSR disclosure on its sector. The modifications made, namely after obtaining the value of a company's CSR disclosure, then it will still be compared to the highest CSR disclosure in the sector.

$$
\text { Related CSRDIit }=\frac{\sum \text { CSRit }}{\sum \operatorname{Max}(\mathrm{CSR} c t)}
$$

Related CSRDI : A company's CSR disclosure index

$\sum$ CSRit : The number of CSR disclosures of a company

$\sum \operatorname{Max}(\mathrm{CSR}$ ct) : The highest number of competitor companies' CSR disclosures

All expenses incurred according to the applicable regulations could be categorized as capital expenditure. Investment policies with considerations of social aspects which have an impact to the breadth of social responsibility which informed if they could accommodate the needs of stakeholders, including the communities who experience direct social and environmental impacts from company activities. The proxy used was CAPEX (Capital Expenditure) as an independent variable.

$$
\text { CAPEX }=\frac{\text { Capital Expenditure }}{\text { Total Asset }}
$$

Organizational strategy is an series of special integrated strategic plans which made to achieve the company goals starting from binding commitments to monitoring or evaluation of the organization's activities that have been carried out. Selling, General and Administrative (SG\&A) Expenses describes the operational costs incurred by the company in implementing organizational strategy, including the costs of disclosing social responsibility.

SG\&A Expense $=\frac{\text { Selling, General and Administrative Expense }}{\text { Total Sales }}$

The company's performance could be assessed from its financial performance. A company could be said have a financial performance when it already conducted a financial analysis whose application is in accordance with good and correct financial rules and principles [33]. ROA (Return on Asset) as one of the profitability ratios could be used as a proxy for the independent variable of company performance.

$$
\mathrm{ROA}=\frac{\text { Earning After Interest and Tax }}{\text { Total Asset }}
$$

Firm size used as a control variable in this research because so many previous research have used this proxy to describe the variations in the disclosures of corporate social responsibility. That because there has a link with stakeholder theory which illustrates that companies that have a larger size would attracted more stakeholders who are more interested in organizational 
Aulia Faza \& Wiwik Utami., Saudi J Bus Manag Stud, Apr, 2021; 6(4): 114-124

activities so their political costs will increase. The large political costs would be suppressed by the company through expressing social responsibility for more broadly [28]. The Firm size that used as a control variable in this research is by measuring the logarithm of the total assets from an organization.

$\mathrm{SIZE}=\log ($ Total Asset $)$

Research and Development (R\&D) Expense is a form of investment with the intention of strengthening knowledge creation within the company, stimulating processes, innovation and product efficiency as well as improvements in stronger products and processes. These improvements do not automatically have to produce improvements related to CSR Performance, but can lead to innovations which simultaneously benefit society and the environment [29]. The proxy used to measure $R \& D$ in this research was $R \& D$ Intensity.

$$
\text { R\&D Intensity }=\frac{\text { R\&D Expense }}{\text { Total Sales }}
$$

The high leverage owned by the company will increase the potential for violation of the agreed debt contract, therefore the company's current earnings reporting would be made bigger than future profits [30, 31]. This effort was made in order to reduce the potential for the company to violate its debt agreement. In order to be capable of increasing this profit, reducing costs arising from organizational activities is one of the options that need to be considered by the company, including reducing the cost of disclosing its social responsibility. Leverage could be measured through the debt ratio of Debt to Equity Ratio (DER) which is often used as a control variable.

$$
\text { DER }=\frac{\text { Total Liabilities }}{\text { Total Equity }}
$$

The research method that was used consists of 3 (three) stages. The first stage is a descriptive test whose function is to manage and systematize quantitative data into a complete picture of a structured activity by frequency, central tendency, dispersion and correlation coefficient as measures. The second stage is the classical assumption test. And the third stage is a hypothesis examination. Furthermore, the last analysis is multiple linear regression analysis to see whether there has an impact which is caused by firm investment policy, organizational strategy, firm performance, firm size, research and development and leverage on corporate social responsibility in manufacturing sector companies which registered and still active on the IDX during 2014 - 2016. The regression equation model used:

$$
C S R=\alpha+\beta 1 F I P+\beta 2 O S+\beta 3 F P+\beta 4 F Z+\beta 5 R D+\beta 6 L E V+\varepsilon
$$

\section{FINDINGS AND DISCUSSION \\ Descriptive Test Analysis}

The average Related CSRDI (Corporate Social Responsibility Disclosure Index) from 2014-2016 was 0.425787 . With the minimum value was 0.1176 at PT. Tempo Scan Pacific Tbk in 2014 and the maximum value was 1.0000 at PT. Indocement Tunggal Prakarsa Tbk in 2014-2015 and PT. Unilever Indonesia Tbk in 2016 with a standard deviation value of 0.2165522 . The average CAPEX (Capital Expenditure) from 2014 2016 was 0.073002 . The minimum value was 0.0001 at PT. Semen Indonesia Tbk in 2016 and the maximum value was 0.2808 at PT. Nippon Indosari Corpindo Tbk in 2014 with standard deviation value of 0.0523133 . The average SG\&A (Sales, General and Administrative) Expense from 2014-2016 was 0.166113. The minimum value was occured 0.0224 at PT. Wijaya Karya Beton Tbk in 2014 and the maximum value was 0.3628 at PT. Nippon Indosari Corpindo Tbk in 2016 with standard deviation value of 0.0977743 . The average ROA (Return On Asset) from 2014-2016 was 0.103344. With the minimum value was -0.2233 goes to PT. Bentoel Internasional Investama Tbk in 2014 while the maximum value was 0.4018 and goes to PT. Unilever Indonesia Tbk in 2014 with standard deviation value of 0.1059562. The average Firm Size from 2014-2016 was 12,952997. The minimum value was 12,1248 at PT. Wismilak Inti Makmur Tbk in 2014 while the maximum value was 14.4181and goes to PT. Astra International Tbk in 2016 with standard deviation value of 0.5451893 . The average R\&D (Research and Development) Expense from 2014-2016 was 0.001651. The minimum value was 0.0000 to PT. Indomobil Sukses Internasional Tbk in 2014 - 2016 and PT. Semen Indonesia (Persero) Tbk in 2015 while the maximum value was 0.0099, goes to PT. Kalbe Farma Tbk in 2016 with standard deviation value of 0.0020333 . The average DER (Debt to Equity Ratio) from 2014 - 2016 was 0.698903 . For the minimum value was -8.3333 , which is goes to PT. Bentoel Internasional Investama Tbk in 2014 while the maximum value was 2,8203 and goes to PT. Indomobil Sukses Internasional Tbk in 2016 with standard deviation value of 1.5680693 . 
Table-1: Descriptive Test Analysis

\begin{tabular}{|l|l|l|l|l|l|}
\hline & $\mathbf{N}$ & Minimum & Maximum & Mean & Std. Deviation \\
\hline CSR & 63 & .1176 & 1.0000 & .425787 & .2165522 \\
\hline CAPEX & 63 & .0001 & .2808 & .073002 & .0523133 \\
\hline SGA & 63 & .0224 & .3628 & .166113 & .0977743 \\
\hline ROA & 63 & -.2223 & .4018 & .103344 & .1059562 \\
\hline SIZE & 63 & 12.1248 & 14.4181 & 12.952997 & .5451893 \\
\hline RnD & 63 & .0000 & .0099 & .001651 & .0020333 \\
\hline DER & 63 & -8.3383 & 2.8203 & .698903 & 1.5680693 \\
\hline Valid N (listwise) & 63 & \multicolumn{3}{|l}{} \\
\hline
\end{tabular}

\section{Classical Assumption Test Analysis}

From this analysis it could be viewed that the distribution of points on the image leads to form the diagonal line, while for the logorov-smirnov test, the
Asymp value. Sig. (2-tailed) was 0.200 which explained that it was greater than 0.05 . The conviction from these two analysis is that the regression model and residual values were normally distributed [32].

Table-2: Normality Test Result with Kolmogorov-Smirnov Test

\begin{tabular}{|c|c|c|}
\hline \multicolumn{3}{|c|}{ One-Sample Kolmogorov-Smirnov Test } \\
\hline & & Residual Non Standard \\
\hline \multicolumn{2}{|l|}{$\mathrm{N}$} & 63 \\
\hline \multirow[t]{2}{*}{ Parameter Normal $^{\mathrm{a}, \mathrm{b}}$} & Average & .0000000 \\
\hline & Std. Dev. & .17597322 \\
\hline \multirow{3}{*}{$\begin{array}{l}\text { The Most Extreme } \\
\text { Difference }\end{array}$} & Absolute & .083 \\
\hline & Positive & .083 \\
\hline & Negative & -.060 \\
\hline \multicolumn{2}{|l|}{ Statistict Test } & .083 \\
\hline \multicolumn{2}{|l|}{ Asymp. Sig. (2-tailed) } & $.200^{\mathrm{c}, \mathrm{d}}$ \\
\hline
\end{tabular}

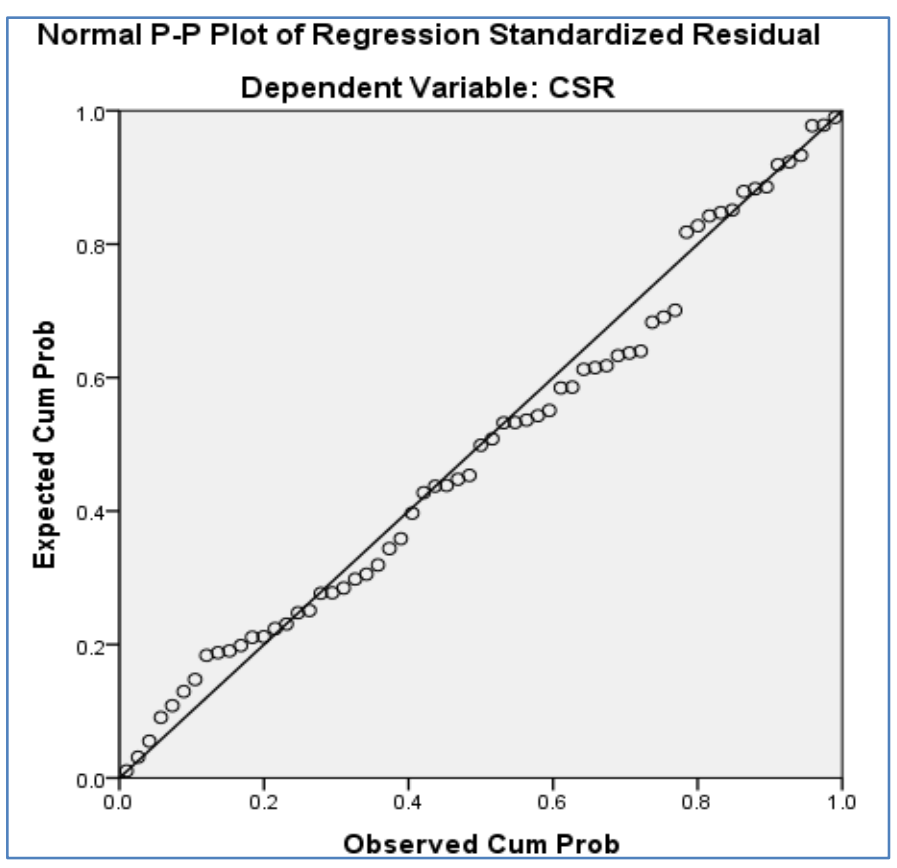

Fig-1: Normality Test with P-P Plot

The basic of decision making is the amount of Tolerance and VIF. The regression model criteria are said to pass the multicollinearity if the VIF value is less than 10 and the Tolerance value is more than 0.1 [32]. According to the table above, it was found that the VIF value of the independent variable was: $\mathrm{CAPEX}=1.136$,
$\mathrm{SG} \& \mathrm{~A}=1.456, \mathrm{ROA}=1.325, \mathrm{SIZE}=1.232, \mathrm{R} \& \mathrm{D}=$ 1.174 and $\mathrm{DER}=1.101$, while the Tolerance value was: CAPEX $=0.881, \mathrm{SG} \& \mathrm{~A}=0.687, \mathrm{ROA}=0.755$, SIZE $=0.812, \mathrm{R} \& \mathrm{D}=0.852$ and $\mathrm{DER}=0.909$. So the conclusion is that the regression model had passed the multicollinearity. 
Table-3: Multicollinearity Test Results

\begin{tabular}{|c|c|c|c|c|c|}
\hline \multicolumn{6}{|c|}{ Coefficients $^{\mathrm{a}}$} \\
\hline \multirow{2}{*}{\multicolumn{2}{|c|}{ Model }} & \multirow[t]{2}{*}{$\mathrm{t}$} & \multirow[t]{2}{*}{ Sig. } & \multicolumn{2}{|c|}{ Collinearity Statistics } \\
\hline & & & & Tolerance & VIF \\
\hline \multirow[t]{7}{*}{1} & (Constant) & -1.615 & .112 & & \\
\hline & CAPEX & 1.942 & .057 & .881 & 1.136 \\
\hline & SGA & .200 & .842 & .687 & 1.456 \\
\hline & ROA & 3.265 & .002 & .755 & 1.325 \\
\hline & SIZE & 2.134 & .037 & .812 & 1.232 \\
\hline & $\mathrm{RnD}$ & -1.630 & .109 & .852 & 1.174 \\
\hline & DER & -.378 & .707 & .909 & 1.101 \\
\hline
\end{tabular}

The Fundamental for making this decision were according to [32] stated that if the dots form a certain regular pattern there is heteroscedasticity, whereas if the dots spread out without forming a certain regular pattern, so it said there is no heteroscedasticity occurs. The descriptions from the results of the heteroscedasticity test is there is no heteroscedasticity occurs.

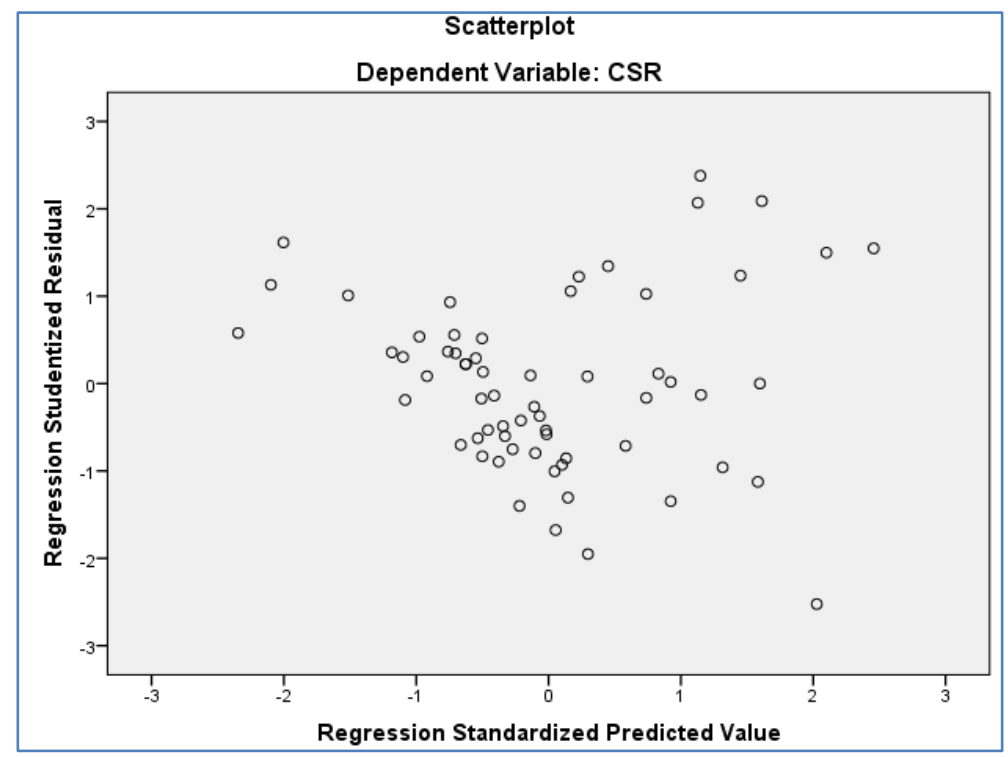

Fig-3: Heteroscedasticity Test Results

According to [32] 3 (three) decisions that could be taken to the Durbin-Watson test are if DU $<$ DW $<4$ DU did not occur autocorrelation, if DW $<$ DL or DW $>4 \mathrm{DL}$ said that the autocorrelation occurs, then and if DL $<\mathrm{DW}<\mathrm{DU}$ or $4 \mathrm{DU}<\mathrm{DW}<4 \mathrm{DL}$ means the conclusion is uncertain. After transforming the data into qualified data which could be fulfill the assumptions underlying the analysis of variance and proceed with the autocorrelation test using the Cochrane Orcutt method, the Durbin-Watson value increases to 2.038 and by referring to the Durbin-Watson table it was obtained that the DL amounted was 1.3918 while the DU amounted was 1.8058 , which means that the regression model passed the autocorrelation test.

Table-4: Autocorrelation Test Results

\begin{tabular}{|c|c|c|c|c|c|c|c|c|c|c|}
\hline \multicolumn{11}{|c|}{ Model Summary ${ }^{c, d}$} \\
\hline \multirow[t]{2}{*}{ Model } & \multirow[t]{2}{*}{$\mathrm{R}$} & \multirow{2}{*}{$\begin{array}{l}\mathrm{R} \\
\text { Square }^{\mathrm{b}}\end{array}$} & \multirow{2}{*}{$\begin{array}{l}\text { Adjusted } \\
\text { R Square }\end{array}$} & \multirow{2}{*}{$\begin{array}{l}\text { Std. Error of } \\
\text { the Estimate }\end{array}$} & \multicolumn{5}{|c|}{ Change Statistics } & \multirow{2}{*}{$\begin{array}{l}\text { Durbin- } \\
\text { Watson }\end{array}$} \\
\hline & & & & & $\begin{array}{l}\text { R Square } \\
\text { Change }\end{array}$ & $\begin{array}{l}\mathrm{F} \\
\text { Change }\end{array}$ & $\begin{array}{l}\mathrm{df} \\
1\end{array}$ & $\begin{array}{l}\mathrm{df} \\
2\end{array}$ & $\begin{array}{l}\text { Sig. F } \\
\text { Change }\end{array}$ & \\
\hline 1 & $.900^{\mathrm{a}}$ & .811 & .791 & .17847 & .811 & 39.995 & 6 & 56 & .000 & 2.038 \\
\hline
\end{tabular}

\section{Hypothesis Test Analysis}

In this research, the H0 (null hypothesis) were explained that investment policy, organizational strategy and financial performance had no impact on the widely of corporate social responsibility information disclosed, while for $\mathrm{Ha}$ (the alternative hypothesis) 
Aulia Faza \& Wiwik Utami., Saudi J Bus Manag Stud, Apr, 2021; 6(4): 114-124

were explains that investment policy, organizational strategy and financial performance will have an affect on the disclosure of corporate social responsibility. According to the table above, the amount of F-counts was 39.995 while the amounted of the $\mathrm{F}$ table with a significance of 0.05 , df $1=5$ and df $2=56$, which is 2.265, it is found that F-Count > F Table it is concluded that H0 was rejected while $\mathrm{Ha}$ was accepted. The
Magnitude of sig $0,000<0.15$ meaning that Capital Expenditure (CAPEX), Sales General and Administrative (SGA) Expense, Return On Asset (ROA), Firm Size, Research and Development (RnD) and Debt Equity Ratio (DER) simultaneously has a significant impact on Related Corporate Social Responsibility Disclosure index (Related CSRDI).

Table-5: F-Test Results

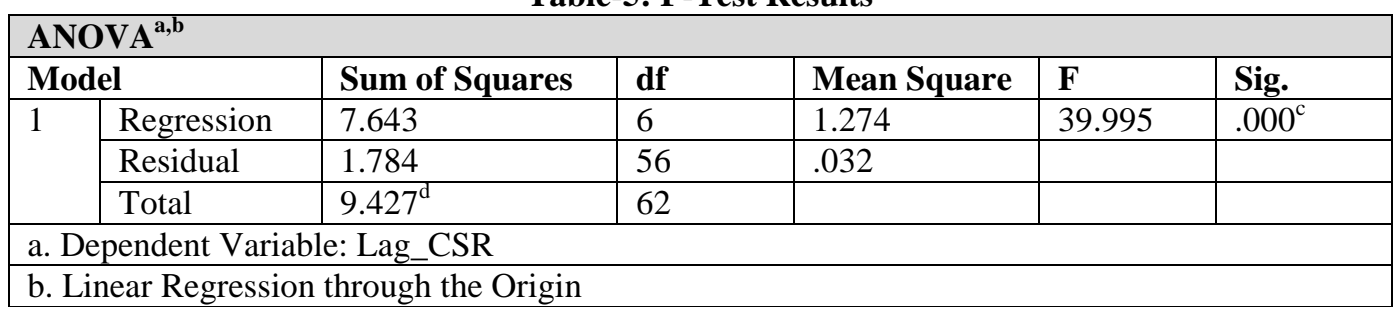

According to the table above, the T-Count value for each variable has been obtained. Based on the significance level of 0.05 , the number of variables is 7 pieces and the number of observations is 63 , then the amount of T-table is 2.003. The conclusion from this analysis is that CAPEX, ROA and SIZE have a significant positive impact, while SGA has an insignificant impact towards a positive direction, while $\mathrm{RnD}$ and DER did not have a significant negative impact on the disclosure of corporate social responsibility.

Table-6: Partially Test Results

\begin{tabular}{|c|c|c|c|c|c|c|}
\hline \multicolumn{7}{|c|}{ Coefficients $^{\mathrm{a}}$} \\
\hline \multirow{2}{*}{\multicolumn{2}{|c|}{ Model }} & \multicolumn{2}{|c|}{$\begin{array}{l}\text { Unstandardized } \\
\text { Coefficients }\end{array}$} & \multirow{2}{*}{$\begin{array}{l}\text { Standardized Coefficients } \\
\text { Beta }\end{array}$} & \multirow[t]{2}{*}{$\mathrm{t}$} & \multirow[t]{2}{*}{ Sig. } \\
\hline & & $\mathrm{B}$ & Std. Error & & & \\
\hline \multirow{7}{*}{1} & (Constant) & -.862 & .461 & & -1.871 & .067 \\
\hline & CAPEX & .982 & .470 & .239 & 2.089 & .041 \\
\hline & SGA & .035 & .270 & .015 & .130 & .897 \\
\hline & $\mathrm{ROA}$ & .897 & .239 & .452 & 3.755 & .000 \\
\hline & SIZE & .106 & .045 & .280 & 2.372 & .021 \\
\hline & $\mathrm{RnD}$ & -13.705 & 12.081 & -.128 & -1.134 & .262 \\
\hline & DER & -.007 & .015 & -.050 & -.438 & .663 \\
\hline
\end{tabular}

The coefficient of determination $\left(\mathrm{R}^{2}\right)$ test which has more than two independent variables is recommended to use the Adjusted R-Square value to get results which closest to the real conditions. According to the output results, the $\mathrm{R}$ Square value was 0.811 . Meaning that the influence of the variable such as Capital Expenditure (CAPEX), Sales General and
Administrative (SGA) Expense, Return On Asset (ROA), Corporate SIZE, Research and Development (RnD) and Debt Equity Ratio (DER) towards the Related Corporate Social Responsibility Disclosure Index (Related CSRDI) has been contributed to $81.1 \%$ while the remaining $18.9 \%$ was influenced by other factors that were not been examined in this research.

Table-6: $\mathbf{R}^{2}$ Test Results

\begin{tabular}{|l|l|l|l|l|l|}
\hline \multicolumn{5}{|l|}{ Model Summary ${ }^{\mathbf{c}, \mathbf{d}}$} \\
\hline Model & $\mathrm{R}$ & R Square $^{\mathrm{b}}$ & Adjusted R Square & Std. Error of the Estimate & Durbin-Watson \\
\hline 1 & $.900^{\mathrm{a}}$ & .811 & .791 & .17847 & 2.038 \\
\hline a. Predictors: Lag_DER, Lag_RnD, Lag_ROA, Lag_CAPEX, Lag_SIZE, Lag_SGA \\
\hline
\end{tabular}

To measure the amounted of the dependent variable based on its independent variables, so this analysis method is needed, one of way is through multiple linear regression method, in which this analysis are recognize the magnitude of the influence from the independent variable on the dependent variable
(Romie, 2017: 154). Based on Table 6, the formula for this multiple linear regression equation such as:

$$
\begin{aligned}
C S R=- & 0.862+0.982 F I P+0.0350 S+0.897 F P+ \\
& 0.106 F Z-13.705 R D-0.007 L E V
\end{aligned}
$$


The outcome from these multiple linear regression analysis results is that if the value of each coefficient of the independent variable is 0 (zero), the impact which cause by variable of Related Corporate Social Responsibility Disclosure Index $(\mathrm{CSR}=\mathrm{Y})$ will decrease by 0.862 . If the Firm Investment Policy variable coefficient $(\mathrm{CAPEX}=\mathrm{X} 1)$ increases by one unit, what would happen is the Related CSR Disclosure Index $(\mathrm{CSR}=\mathrm{Y})$ variable will increase by 0.120 assuming the value of the other independent variables remains constant. This phenomenon shows that investment policy affects the disclosure of corporate social responsibility. These results reveal that through the increase in investment policy, the company could carry out more activities to reach the stakeholders' expectations of the overall investment policy. Stakeholders will demand the company to disclose its investment policy activities as a form of corporate social responsibility in managing its resources, then it will directly affect the level of disclosure of corporate social responsibility to become more comprehensive. In the end, these results were in accordance with agency theory, stakeholder theory and also support the research of Erhemjamts et al. [17].

If the value of coefficient variables various strategy $(\operatorname{sga}=x 2)$ increases one unit, it is the Shared CSR disclosure index $(\mathrm{CSR}=\mathrm{y})$ and 0.827 reduction on the assumption that other independent variable values remain. The results of this research are incompatible with research conducted by Erhemjamts et al. [17], which suggests that there has a significant impact of organization's strategy on corporate social responsibilities, but it supports gazizova research [34], with an average increase in corporate social responsibility will not always be link to Sales General and Administrative Expense. This difference in results might cause of the disproportionality of the standards used to measure dependent variables. Another likely cause is the difference in the risk between manufacturing and mining companies in which mining companies have higher risk and complexity of business activities than manufacturing companies. The increase in the contribution of the stakeholders to the fact that the government is still developing.

If the Firm Performance variable coefficient $(\mathrm{ROA}=\mathrm{X} 3)$ is increased by one unit, so what happens here is the Related CSR Disclosure Index (CSR = Y) variable will get an increase of 0.035 with the condition that the value on other variables is fixed. According to the results from multiple linear regressions, it shows that company performance had an impact towards the disclosure of corporate social responsibility. These results was illustrated that as the company's performance increases, the company has more resources which could be used to improve the quality and quantity of activities that have been and will be carried out, so there will be an increase in the widely disclosed of corporate social responsibility information, with which the company hopes to get legitimacy from the community in form of support for company activities by increasing the use of its products by the society which will turn into continuously improve the company performance. This was in line with the theory of legitimacy and stakeholder theory which also supports research which was conducted by Erhemjamts et al. [17].

If the coefficient value of the Firm Size variable $(\mathrm{SIZE}=\mathrm{X} 4)$ is increased by one unit, then what happens is the variable Related CSR Disclosure Index $(\mathrm{CSR}=\mathrm{Y})$ will decrease by 0.756 with the condition that the value of other variables should be fixed. These results reveal that the firm size affects the broadly disclosed corporate social responsibility information. These results were also indicate that companies which have a large size will attract lots of attention from stakeholders whose interests and need to be facilitated by the company. These interests will encourage the companies to disclose more comprehensive social responsibility to stakeholders. Then this also strengthens the research from Erhemjamts et al. [17].

If the coefficient value of the Research and Development variable $(\mathrm{RnD}=\mathrm{X} 5)$ increased by one unit, what happens here was the Related CSR Disclosure Index $(\mathrm{CSR}=\mathrm{Y})$ variable would gradually decrease to a value of 14.567 with notes that the value of other variables should be fixed. This opposite to the research from Erhemjamts et al. [17], however, is still appropriate and supports Gazizova's research [34] which stated that on average an increase in Corporate Social Responsibility is not always linked to an increase in Research and Development Expense. This difference in research results could be caused by the inequality of the measurement data standards used in the dependent variable. Another likely cause there is a difference in the risk of business activities between companies in the manufacturing sector and those companies in the mining sector, in which mining sector companies have a higher risk and complexity of business activities, so the focus of research and development would be widely covering to environmental and community aspects.

If the amount of the Leverage variable coefficient (DER = X6) is increased by one unit, what happens here is the variable Related to CSR Disclosure Index $(\mathrm{CSR}=\mathrm{Y})$ will decrease in succession by 0.869 if it is assumed that the amount of the other independent variables is constant. This illustrated that the corporate social responsibility disclosure is not influenced by debt policy. These results show that the higher the company's debt policy causes the financial burden to be borne by the company and become increasingly difficult and could burden the company's performance. Even so, the company still has to disclose its corporate social responsibility to stakeholders as a form of management responsibility in order to maintain the company's 
credibility even though it is modest. This is according to the results from previous research which was conducted by Erhemjamts et al. [17].

\section{CONCLUSION AND SUGGESTION Conclusion}

The conclusions from all analyzes that have been accomplished with various methods which according to the results of the analysis are: First, the investment policy by considering social and environmental aspects is an investment policy oriented on long-term sustainability investment so it would affect the breadth of information in corporate social responsibility that will be disclosed. Second, there are the gaps between the results from previous research related to organizational strategy. This might be of the different proxies that are used, the risks of different business sectors and so on, then the organizational strategy which is carried out is different. In this research, the organizational strategy was carried out by companies in the manufacturing sector and did not show a significant impact on the breadth of disclosed corporate social responsibility information. Third, companies with good performance have significant roles in expressing corporate social responsibility that has been done to improve their product image and corporate image, which ultimately improves company performance on continuous basics. Fourth, the companies that have a large size will attract more attention from stakeholders whose interests that need to be facilitated by the company, thus it would significantly influence the company to disclose more broadly relates to social responsibility that has taken to reduce the incidence of political costs. Fifth, most companies in the manufacturing sector have an allocation of Research and Development Expense, but most companies choose not to disclose this information because it is classified as company secrets, so it has an insignificant negative impact on disclosure of corporate social responsibility. Sixth, companies with a high level of Debt Equity Ratio will still inform the company of social responsibility even though it is modest, while companies will focus on reducing debt ratios for better company performance.

\section{SUGGESTION}

Elicited from the discussion results and those conclusions above regarding the research that has been completed, the writer would like to make several suggestions. First, for the company who greatly and comprehensively inform its social responsibility and require this analysis results as an input in decisions making to reveal corporate social responsibility in order to provide maximum impact to stakeholders. Second, for investors, this research probably could be used as additional information in making investment decisions by considering aspects of corporate social responsibility in order to reduce investment risk. Third, as for further research, there are several suggestions that need to be considered by future researchers who are interested in conducting similar research, such as further researchers are expected to use other methods to research and add non-financial variables in their research model to obtain more diverse research results. And then, the next researcher is expected to be able to use ratio data on each research variable. Avoid using index data (data between 0-1) because it is feared that the planned model will not pass the classical assumption test. And last, the next researcher is expected to be able to increase the number of references to related journals which would be useful to obtain more comprehensive pictures from the potential research.

\section{REFERENCES}

1. News by Liputan6. (January, $18^{\text {th }}$ 2016). $20 \%$ Perusahaan di Malang Tak Masuk Standar Pengolahan Limbah Cair. Jakarta. https://www.liputan6.com/regional/read/2414566/2 0-perusahaan-di-malang-tak-masuk-standarpengolahan-limbah-cair

2. News by Beritasatu. (December, $9^{\text {th }} 2016$ ). Cemari Lingkungan, 7 Perusahaan di Bengkulu Dijatuhi Sanksi. Jakarta. https://www.beritasatu.com/nasional/403694/cemar i-lingkungan-7-perusahaan-di-bengkulu-dijatuhisanksi

3. News by Sindonews. (April, $3^{\text {th }}$ 2017). Miris, 30 Pabrik di Dayeuhkolot Buang Limbah ke Sungai. Bandung. https://daerah.sindonews.com/berita/1193865/21/m iris-30-pabrik-di-dayeuhkolot-buang-limbah-kesungai

4. Siregar, C.N. (2007). Analisis Sosiologis terhadap Implementasi CSR Pada Masyarakat Indonesia. Jurnal Sosioteknologi, 12(6), 285-288.

5. Freeman, R.E. (1984). Strategic Management: A Stakeholder Approach. Pitman Publishing, Boston.

6. Chariri, A., \& Ghazali, I. (2007). Teori Akuntansi. Semarang: Badan Penerbit UNDIP.

7. Rudito, B., Budimanta, A., \& Prasetijo, A. (2004). Corporate Social Responsibility: Jawaban Bagi Modal Pembangunan Indonesia Masa Kini. Jakarta: ICSD.

8. Donaldson, T., \& Preston, L. E. (1995). The Stakeholder Theory of the Corporation: Concepts, Evidence, and Implications. The Academy of Management Review, 20(1), 65.

9. Husnan, A. (2013). Pengaruh Corporate Social Responsibility (CSR Disclosure) Terhadap Kinerja Keuangan Perusahaan. Skripsi. Universitas Diponegoro: Semarang.

10. Villing, R., Timoney, J., \& Ward, T. E. (2004). Automatic blind syllable segmentation for continuous speech.

11. McWilliams, A., \& Siegel, D. (2001). Corporate social responsibility : A theory of the firm perspective. The Academy of Management Review, 26(1), 117-127. 
Aulia Faza \& Wiwik Utami., Saudi J Bus Manag Stud, Apr, 2021; 6(4): 114-124

12. Jones, C. (1995). R \& D-Based Models of Economic Growth. Journal of Political Economy, 103(4), 759784. Retrieved March 18, 2021, from http://www.jstor.org/stable/2138581

13. Wernerfelt, B. (1984). A resource-based view of the firm. Strategic Management Journal, 5(2), 171180.

14. Barney, J. (1991). Firm Resources and Sustained Competitive Advantage. Journal of Management, 17(1), 99-120.

15. Hart, S. L. (1995). A Natural-Resource-Based View of the Firm. The Academy of Management Review, 20(4), 986.

16. Salancik, G. R., \& Pfeffer, J. (1978). A social information processing approach to job attitudes and task design. Administrative science quarterly, 224-253.

17. Erhemjamts, O., Li, Q., \& Venkateswaran, A. (2012). Corporate Social Responsibility and Its Impact on Firms' Investment Policy, Organizational Structure, and Performance. Journal of Business Ethics, 118(2), 395-412.

18. Boaventura, J. M. G., Silva, R. S. da., \& Bandeirade-Mello, R. (2012). Corporate Financial Performance and Corporate Social Performance: Methodological Development and the Theoretical Contribution of Empirical Studies. Revista Contabilidade \& Financas, 23(60), 232-245.

19. Lynch, J. P., \& Loh, K. J. (2006). A summary review of wireless sensors and sensor networks for structural health monitoring. Shock and Vibration Digest, 38(2), 91-130.

20. Wibisono, D. (2006). Manajemen Kinerja, Konsep, Desain, dan Teknik Meningkatkan Daya Saing Perusahaan. Jakarta: Erlangga.

21. Irnawati, J.E., \& Prasetyo, J.H. (2020). The Influence Over the Transformational of Leadership Style, the Organizational Culture, and Employee Empowerment towards Achievement of Organizational Strategies in one the Central Government Organization. International Journal of Innovative Science and Research Technology, 5(3), 917-927.

https://ijisrt.com/assets/upload/files/IJISRT20MAR 333.pdf

22. Porter, J., Craven, B., Khan, R. M., Chang, S.-J., Kang, I., Judkewitz, B., \& Sobel, N. (2006). Mechanisms of scent-tracking in humans. Nature Neuroscience, 10(1), 2729. doi:10.1038/nn1819
23. Orlitzky, M., Schmidt, F. L., \& Rynes, S. L. (2003). Corporate Social and Financial Performance: A Meta-Analysis. Organization Studies, 24(3), 403-441.

24. Margolis, J. D., \& Walsh, J. P. (2003). Misery loves companies: Rethinking social initiatives by business. Administrative science quarterly, 48(2), 268-305.

25. Surroca, J., Tribó, J. A., \& Waddock, S. (2009). Corporate responsibility and financial performance: the role of intangible resources. Strategic Management Journal, 31(5), 463490. doi:10.1002/smj.820

26. Nelling, E., \& Webb, E. (2008). Corporate social responsibility and financial performance: the "virtuous circle" revisited. Review of Quantitative Finance and Accounting, 32(2), 197-209.

27. Castro, J. J., Bernard, J. K., Mullis, N. A., Eggleston, R. B. (2010). Brown midrib corn silage and Tifton 85 bermudagrass in rations for earlylactation cows. J. Dairy Sci., 93, 2143-2152.

28. Sembiring, E.R. (2005). Karakteristik Perusahaan dan Pengungkapan Tanggung Jawab Sosial: Study Empiris pada Perusahaan yang Tercatat di Bursa Efek Jakarta. Simposium Nasional Akuntansi 8, Universitas Negeri Sebelas Maret, Solo.

29. Padgett, R. C., \& Galan, J. I. (2009). The Effect of R\&D Intensity on Corporate Social Responsibility. Journal of Business Ethics, 93(3), 407-418.

30. Anggraini, F. R. R. (2006). Pengungkapan informasi sosial dan faktor-faktor yang mempengaruhi pengungkapan informasi sosial dalam laporan keuangan tahunan (Studi empiris pada perusahaan-perusahaan yang terdaftar Bursa Efek Jakarta). Simposium Nasional Akuntansi, 9(23-26).

31. Trisnawati, R. (2014). Pengaruh Ukuran Perusahaan, Profitabilitas, Leverage, Ukuran Dewan Komisaris Dan Kepemilikan Manajerial Terhadap Pengungkapan Corporate Social Responsibility. Seminar Nasional dan Call for Papper ISBN: 978-602-70429-2-6.

32. Romie, P. (2017). Buku Sakti Kuasai SPSS Pengelolaan data dan Analisis data. Yogyakarta: Start Up.

33. Fahmi, I. (2013). Analisis Laporan Keuangan. Bandung: Alfabeta.

34. Gazizova, A., Mingazova, N., \& Subich, V. (2018). Teaching a Second Foreign Language in the Russian School. SHS Web of Conferences, 48, 01001 . 